\title{
Risks of mild hypertension: a ten-year report
}

\author{
Oglesby Paul ${ }^{1}$ \\ From the Participating Centers in the Pooling Project of the Council on Epidemiology \\ of the American Heart Association
}

Data relating to the risks of hypertension are presented from six prospective studies of cardiovascular disease initiated in the United States 1948-1958. 6640 men, aged 30 to 59 when first seen, were followed for Io years and observations recorded on morbidity from cardiovascular disease and mortality from all causes as well as from cardiovascular disease. Diastolic blood pressures of 85 to $104 \mathrm{~mm}$. Hg as recorded on the initial visit have unfavourable implications in terms of total death rate, deaths from coronary disease, major coronary events (non-fatal myocardial infarctions and deaths from coronary disease), and cerebrovascular episodes. The deleterious effect is most conspicuous in men in their fifties, but also appears in the younger age groups.

The relaxed attitude of the medical profession and of the public to the existence of a mild to moderate systemic arterial hypertension has been partially replaced by one of greater vigilance in recent years. The increased, but as yet inadequate, awareness of the unfavourable impact of high blood pressure on health has come from a combination of clinical and epidemiological reports (Lew, 1967; Mathisen et al., 1969; Paul and Ostfeld, 1965; Sokolow and Perloff, I96r; Veterans Administration Cooperative Study Group on Antihypertensive Agents, 1967). There is need to document better the magnitude of this unfavourable impact. It is hoped that this report will provide further documentation.

\section{The pooling project}

The Council on Epidemiology of the American Heart Association, working with the National Heart and Lung Institute of the National Institutes of Health, undertook to sponsor and support a pooling of data from six prospective studies of cardiovascular disease initiated in the United States 1948-58. The centres participating, the types of populations studied, and the principal investigators were: Albany, New York, civil servants, Dr. Joseph T. Doyle; Chicago, Illinois, workers in light industry (Western Electric Company), Dr. Oglesby Paul; Chicago, Illinois, clerical and light industrial workers (People's

1 Address: Passavant Memorial Hospital, 303 East Superior Street, Chicago, Illinois 606 I I, U.S.A.
Gas Company), Dr. Jeremiah Stamler; Framingham, Massachusetts, a community sample in a suburb, Drs. Thomas R. Dawber and William B. Kannel; Los Angeles, California, civil servants, Dr. John M. Chapman; Minneapolis, Minnesota, business and professional men, Dr. Ancel Keys. The co-ordination of the project was under the supervision of Dr. Frederick H. Epstein and Prof. Felix E. Moore of the School of Public Health, University of Michigan. The statistical material included in this report was assembled by Mr. Thomas M. Karunas.

Nature of the data The data reported are from white men only, aged 30 to 59 on admission to their respective studies. All subjects were considered free of clinical coronary heart disease on entrance into the study, but there were no exclusions because of other problems in health, including diabetes. All were followed for ten years respectively, and records obtained of impairments of health with especial emphasis on heart attacks, cerebrovascular episodes, and deaths from all causes. Because of the size of the joint study, it will be noted that in some categories complete data are not as yet available, and this report should be considered as a first report, to be followed by more detailed analyses.

The blood pressures were those obtained in the left arm at the beginning of the physical examination with the subject seated, with the exception of one study in which, if an elevated blood pressure was found, the lowest of three 
blood pressures taken at the initial examination were used. Only the diastolic values will be used in the analyses. In analysing the data, it was decided to divide the population into four groups by diastolic blood pressure, emphasizing the pressures themselves rather than an arbitrary definition of mild hypertension. The first group, below $85 \mathrm{~mm}$. $\mathrm{Hg}$, would be accepted by most physicians as having a satisfactory diastolic level. The second group, 85 to $94 \mathrm{~mm}$., would usually be looked upon as having upper limit of normal to mildly hypertensive pressures. The third group, 95 to I04 mm., would, we believe, be clearly accepted as a category of mild hypertension. The fourth group, greater than I04 mm., includes what most doctors would describe as moderate to severe hypertension as well as some instances of a mild hypertension. It is our belief that the findings reported represent essentially the course of untreated hypertension. It is true that some of the subjects did receive antihypertensive drugs and dietary advice at some time during the ten years. However, long-term, continuous effective therapy was infrequent. For example, in 60 consecutive individuals with diastolic blood pressures of $105 \mathrm{~mm}$. $\mathrm{Hg}$ or more when first seen in one study who were reported to the family or company physician, the diastolic pressures in 29 were lower at 5 years, and in 31 were the same or higher. Of the 29 subjects with lower pressures, one had continuous treatment, 8 had incontinuous treatment, and 20 had no treatment. Of the 31 with higher diastolic blood pressures, one had continuous treatment, 13 had incontinuous treatment, and 17 had no treatment.

Number of subjects The base population consists of 1211 men aged 30 to 39 when first examined, 3460 aged 40 to 49 , and 1969 aged 50 to 59. The total of 6640 men excludes 806 individuals lost to follow-up.

Blood pressure and age Table I shows the distribution of the base population by age at entry into the studies and by diastolic blood pressure. It is apparent that the chief difference in the older as contrasted with the younger age group is a smaller fraction of men in the lowest blood pressure category and a slightly greater fraction of individuals in the other three categories. It is also evident that distinct elevations of diastolic blood pressure were encountered in as many as 13 per cent of men in their thirties and 21 per cent in their fifties.
TABLE I Distribution of base population by age and level of diastolic blood pressure

\begin{tabular}{lccc}
\hline $\begin{array}{l}\text { Diastolic } \\
\text { blood } \\
\text { pressure } \\
(m m . H g)\end{array}$ & \begin{tabular}{l} 
Age at entry \\
\cline { 2 - 4 }$(N 0-39$
\end{tabular} & $\begin{array}{l}40-49 \\
(N=3460)\end{array}$ & $\begin{array}{l}50-59 \\
(N=1969)\end{array}$ \\
\hline$<85$ & $61 \%$ & $53 \%$ & $50 \%$ \\
$85-94$ & $26 \%$ & $29 \%$ & $29 \%$ \\
$95-104$ & $10 \%$ & $13 \%$ & $13 \%$ \\
$>104$ & $3 \%$ & $5 \%$ & $8 \%$ \\
\hline & $100 \%$ & $100 \%$ & $100 \%$ \\
\hline
\end{tabular}

Blood pressure and relative weight The distribution of the population by relative weight (ratio of actual weight to recommended weight of Metropolitan Life Insurance Company, 1959) and diastolic blood pressure is shown in Table 2. The population has been

TABLE 2 Distribution of base population by relative weight and diastolic blood pressure

\begin{tabular}{lcccc}
\hline $\begin{array}{l}\text { Diastolic } \\
\text { blood pressure } \\
(m m . H g)\end{array}$ & \multicolumn{2}{l}{ Relative weight } & & \\
\cline { 2 - 4 } & $\begin{array}{l}\text { (I.IO } \\
(N=2648)\end{array}$ & $\begin{array}{l}I \cdot I 0-I \cdot 2 I \\
(N=I 82 I)\end{array}$ & $\begin{array}{l}>I \cdot 2 I \\
(N=2 I 7 I)\end{array}$ & $\begin{array}{l}\text { Total } \\
(N=6640)\end{array}$ \\
\hline$<85$ & $67 \%$ & $53 \%$ & $39 \%$ & $54 \%$ \\
$85-94$ & $23 \%$ & $30 \%$ & $33 \%$ & $28 \%$ \\
$95-104$ & $8 \%$ & $12 \%$ & $18 \%$ & $12 \%$ \\
$>104$ & $2 \%$ & $5 \%$ & $10 \%$ & $6 \%$ \\
\hline & $100 \%$ & $100 \%$ & $100 \%$ & $100 \%$ \\
\hline
\end{tabular}

divided into three roughly similarly sized groups by relative weight by using cut-off points of $I \cdot I O$ and $I \cdot 2 r$. The obvious and consistent increase in the frequency of higher levels of diastolic blood pressure with increases in relative weight is shown.

Deaths from all causes The rates of death per 10,000 from all causes by age and diastolic blood pressure are shown in Table 3

TABLE 3 Deaths from all causes: ten-year rates/10,000 by age and diastolic blood pressure

\begin{tabular}{lccc}
\hline $\begin{array}{l}\text { Diastolic } \\
\text { blood pressure } \\
(\mathrm{mm} . \mathrm{Hg})\end{array}$ & $\begin{array}{r}\text { Age 30-39 } \\
(N=1193)\end{array}$ & $\begin{array}{l}\text { Age 40-49 } \\
(N=3413)\end{array}$ & $\begin{array}{l}\text { Age 50-59 } \\
(N=1956)\end{array}$ \\
\hline$<85$ & 45 & 299 & 635 \\
$85-94$ & 198 & 437 & 932 \\
$95-104$ & 360 & 353 & 1264 \\
$>104$ & 0 & 1186 & 1534 \\
\hline Combined rate & 126 & 398 & 900 \\
\hline
\end{tabular}


and include 327 deaths. As might be expected, the number of events is low in the men in the thirties. A rising mortality with the higher ranges of diastolic pressure is most clearly demonstrated in the fifties, but also occurs in the forties with a plateau in the middle two blood pressure groups. The presence of 'mild' hypertension appears in all of the groups to be unfavourable in terms of total mortality.

Deaths from coronary heart disease The deaths from coronary heart disease were classified into sudden ( 143 cases) and nonsudden (70 cases) and are listed in Table 4. For purposes of this study a sudden death was diagnosed when the individual was not known to have had prior coronary heart disease and died within 3 hours of the onset of acute symptoms. An additional group of 50 coronary deaths with final illnesses of as yet uncertain duration are not included in these computations but are included in Tables 5-8 under total coronary events. At all ages and at essentially all blood pressure ranges, sudden death as defined was more common than nonsudden death. Again, the numbers in the thirties are relatively few and are statistically not significant. In the two older age groups, however, we find a strong association of sudden death with the highest diastolic blood pressure values. This is less impressive among the non-sudden deaths, although the trend at all ages favours a positive association with the more elevated diastolic blood pressure readings.

Non-fatal myocardial infarctions and deaths from coronary disease Table 5 combines non-fatal myocardial infarctions ( 325 cases) and deaths from coronary disease, including sudden deaths, to give a picture of all major coronary events. In all age groups there is a progressive increase in the incidence rates with rises in the diastolic blood pressures. Blood pressures in the range 85 to 94 $\mathrm{mm}$. $\mathrm{Hg}$ were associated with an excess morbidity and mortality from coronary events, as compared with blood pressures below 85 . The range of risk from the lowest to the highest diastolic blood pressure group was over tenfold in the thirties, more than threefold in the forties, and more than twofold in the fifties.

Blood pressure, age, coronary events, and other factors It is possible to use the pooled data to combine the blood pressure findings with other factors to assess the con- sequences on cardiovascular health, although here, as the number of subjects in each category is smaller, individual rates become less meaningful and trends only should be emphasized. In terms of non-fatal myocardial infarctions and coronary deaths combined, the men whose serum cholesterol concentrations were $255 \mathrm{mg}$./100 ml. or greater had higher rates, at all three age groups, than did men with cholesterol concentrations less than 255 $\mathrm{mg}$./100 ml. (Table 6). The rates were generally higher in those with mild hypertension than in those with the lowest diastolic values: however, in the two older decades in the subjects with the most severe hypertension the attack rate appeared independent of the

TABLE 4 Deaths from coronary heart disease, sudden and nonsudden: ten-year rates/10,000 by age and diastolic blood pressure

\begin{tabular}{|c|c|c|c|c|c|c|}
\hline $\begin{array}{l}\text { Diastolic } \\
\text { blood pressure } \\
(\mathrm{mm} . \mathrm{Hg})\end{array}$ & $\begin{array}{l}\text { Age } 30- \\
\text { Sudden }\end{array}$ & $\begin{array}{c}39(N=I 193) \\
\text { Non-sudden }\end{array}$ & $\begin{array}{l}\text { Age 40- } \\
\text { Sudden }\end{array}$ & $\begin{array}{l}9(N=340 I) \\
\text { Non-sudden }\end{array}$ & $\begin{array}{l}\text { Age 50-5 } \\
\text { Sudden }\end{array}$ & $\begin{array}{c}9(N=1938) \\
\text { Non-sudden }\end{array}$ \\
\hline$<85$ & 30 & 0 & 135 & 47 & 257 & I79 \\
\hline $85-94$ & 142 & 28 & 175 & 88 & 419 & 252 \\
\hline 95-I04 & 72 & 216 & I88 & 21 & 528 & 340 \\
\hline$>104$ & 0 & 0 & 628 & I 57 & 604 & 275 \\
\hline Combined rate & 67 & 34 & 182 & 62 & 377 & 232 \\
\hline
\end{tabular}

TABLE 5 Total non-fatal myocardial infarctions and all coronary deaths: ten-year rates/10,000 by age and diastolic blood pressure

\begin{tabular}{lccc}
\hline $\begin{array}{l}\text { Diastolic } \\
\text { blood pressure } \\
(m m . ~ H g)\end{array}$ & $\begin{array}{l}\text { Age 30-39 } \\
(N=1193)\end{array}$ & $\begin{array}{l}\text { Age 40-49 } \\
(N=3413)\end{array}$ & $\begin{array}{l}\text { Age 50-59 } \\
(N=1956)\end{array}$ \\
\hline$<85$ & 106 & 603 & 858 \\
$85-94$ & 538 & 680 & 1431 \\
$95-104$ & 576 & 707 & 1896 \\
$>104$ & 1463 & 1907 & 2116 \\
\hline Combined rate & 335 & 715 & 1299 \\
\hline
\end{tabular}

cholesterol value. When the habit of cigarette smoking at entry into the studies was considered (Table 7), without regard to the number of cigarettes smoked, a trend in incidence proportional to diastolic pressure is seen whether the subject was a cigarette smoker or not. Also, in general, at any diastolic blood pressure non-cigarette smokers fared better than smokers. At the highest blood pressure level the additional liability imposed by the cigarette habit was less striking and no effect at all could be demonstrated in those beyond 
TABLE 6 Total non-fatal myocardial infarctions and all coronary deaths: ten-year rates/10,000 by age, diastolic pressure, and serum cholesterol

\begin{tabular}{|c|c|c|c|c|c|c|c|}
\hline \multicolumn{2}{|c|}{ Cholesterol (mg./ $100 \mathrm{ml})$. } & \multicolumn{2}{|l|}{ Age $30-39$} & \multicolumn{2}{|l|}{ Age $40-49$} & \multicolumn{2}{|l|}{ Age $50-59$} \\
\hline & & $\begin{array}{l}<255 \\
(N=902)\end{array}$ & $\begin{array}{l}\geqslant 255 \\
(N=291)\end{array}$ & $\begin{array}{l}<255 \\
(N=2393)\end{array}$ & $\begin{array}{l}\geqslant 255 \\
(N=1020)\end{array}$ & $\begin{array}{l}<255 \\
(N=1266)\end{array}$ & $\begin{array}{l}\geqslant 255 \\
(N=688)\end{array}$ \\
\hline $\begin{array}{l}\text { Diastolic blood } \\
\text { pressure } \\
(\mathrm{mm} . \mathrm{Hg})\end{array}$ & $\begin{array}{c}<85 \\
85-94 \\
95-104 \\
>104\end{array}$ & $\begin{array}{r}79 \\
420 \\
283 \\
1154\end{array}$ & $\begin{array}{c}197 \\
879 \\
1515 \\
2000\end{array}$ & $\begin{array}{r}438 \\
548 \\
517 \\
1947\end{array}$ & $\begin{array}{r}1064 \\
952 \\
1118 \\
1852\end{array}$ & $\begin{array}{r}686 \\
1237 \\
1404 \\
2203\end{array}$ & $\begin{array}{l}1204 \\
1711 \\
2778 \\
1972\end{array}$ \\
\hline Combined rate & & 233 & 653 & 552 & 1098 & 1090 & 1657 \\
\hline
\end{tabular}

TABLE 7 Total non-fatal myocardial infarctions and all coronary deaths: ten-year rates/10,000 by age, diastolic pressure, and cigarette smoking

\begin{tabular}{|c|c|c|c|c|c|c|}
\hline \multirow{2}{*}{$\begin{array}{l}\text { Diastolic blood } \\
\text { pressure } \\
(\mathrm{mm} . \mathrm{Hg})\end{array}$} & \multicolumn{2}{|l|}{ Age $30-39$} & \multicolumn{2}{|l|}{ Age $40-49$} & \multicolumn{2}{|l|}{ Age $50-59$} \\
\hline & $\begin{array}{l}\text { Non-smoker } \\
(N=392)\end{array}$ & $\begin{array}{l}\text { Smoker } \\
(N=786)\end{array}$ & $\begin{array}{l}\text { Non-smoker } \\
(N=1369)\end{array}$ & $\begin{array}{l}\text { Smoker } \\
(N=1998)\end{array}$ & $\begin{array}{l}\text { Non-smoker } \\
(N=908)\end{array}$ & $\begin{array}{l}\text { Smoker } \\
(N=987)\end{array}$ \\
\hline$<85$ & 52 & 131 & 230 & 798 & $66 I$ & 882 \\
\hline $85-94$ & 217 & 660 & 402 & 871 & 847 & 1702 \\
\hline $95-104$ & 0 & 899 & 348 & 945 & 1493 & 1803 \\
\hline$>104$ & 1333 & $153^{8}$ & 1304 & 2323 & 2277 & 1905 \\
\hline Combined rate & 153 & 407 & 373 & 916 & 1024 & 1317 \\
\hline
\end{tabular}

TABLE 8 Total non-fatal myocardial infarctions and coronary deaths: ten-year rates/10,000 by age, diastolic pressure, and relative weight

\begin{tabular}{|c|c|c|c|c|c|c|c|}
\hline \multirow[t]{2}{*}{ Relative weight } & & \multicolumn{2}{|l|}{ Age $30-39$} & \multicolumn{2}{|l|}{ Age 40-49 } & \multicolumn{2}{|l|}{ Age 50-59 } \\
\hline & & $\begin{array}{l}<I \cdot 2 I \\
(N=802)\end{array}$ & $\begin{array}{l}\geqslant I \cdot 2 I \\
(N=39 I)\end{array}$ & $\begin{array}{l}<I \cdot 2 I \\
(N=23 I 0)\end{array}$ & $\begin{array}{l}\geqslant I \cdot 2 I \\
(N=I I 03)\end{array}$ & $\begin{array}{l}<I \cdot 2 I \\
(N=I 267)\end{array}$ & $\begin{array}{l}\geqslant I \cdot 2 I \\
(N=687)\end{array}$ \\
\hline $\begin{array}{l}\text { Diastolic blood } \\
\text { pressure } \\
\text { (mm. Hg) }\end{array}$ & $\begin{array}{c}<85 \\
85-94 \\
95-104 \\
>104\end{array}$ & $\begin{array}{r}77 \\
531 \\
159 \\
2000\end{array}$ & $\begin{array}{r}217 \\
548 \\
921 \\
1290\end{array}$ & $\begin{array}{r}519 \\
595 \\
615 \\
1647\end{array}$ & $\begin{array}{r}877 \\
829 \\
814 \\
2110\end{array}$ & $\begin{array}{r}889 \\
1500 \\
2121 \\
2125\end{array}$ & $\begin{array}{r}766 \\
1273 \\
1618 \\
2110\end{array}$ \\
\hline Combined rate & & 224 & 563 & 593 & 970 & 1279 & 1310 \\
\hline
\end{tabular}

fifty who had diastolic pressures in excess of 104 $\mathrm{mm}$. Hg. Relative weight was also studied in relation to the age, blood pressure, and combined coronary events (Table 8). The differences in the rates of coronary events at the four blood pressure levels between those with relative weights of $I \cdot 2 I$ or more and those of less than $I \cdot 2 \mathrm{I}$ were modest in the thirties and forties, in favour of those nearest the recommended weight, and the differences ceased to exist in the fifties. Using the presence or absence in the electrocardiograms of $S-T$ junction and segment depressions and $T$ wave abnormalities (Minnesota codes $4-I$, $4-2,5-1$, and 5-2) in the absence of ventricular conduction defects, it was observed that the existence of such abnormalities was clearly unfavourable at all age levels. Although the presence of such electrocardiographic findings was clearly ominous, the relation to blood pressure levels was less clearly demonstrated, although those with the highest diastolic blood pressures fared least well. Using sudden death alone, without including non-fatal myocardial infarctions and non-sudden coronary deaths, the results are in general similar. An additional approach towards non-fatal myocardial infarctions and total coronary deaths, made by contrasting those men who did not smoke cigarettes and had serum cholesterol concentrations below $255 \mathrm{mg}$./100 ml. with those who did smoke and also had serum cholesterol values of $255 \mathrm{mg}$./100 ml. or above (Table 9), reveals an association with the diastolic blood pressure levels, especially in the men in the thirties who smoked and had 
TABLE 9 Total non-fatal myocardial infarctions and all coronary deaths: ten-year rates/10,000 by age, diastolic pressure, smoking, and serum cholesterol

\begin{tabular}{|c|c|c|c|c|c|}
\hline \multicolumn{2}{|c|}{ Cholesterol (mg./ $100 \mathrm{ml})}$. & \multicolumn{2}{|l|}{ Age $30-39$} & \multicolumn{2}{|l|}{ Age 50-59 } \\
\hline & & $\begin{array}{l}\text { Non-smoker } \\
<255(N=309)\end{array}$ & $\begin{array}{l}\text { Smoker } \\
\geqslant 255(N=203)\end{array}$ & $\begin{array}{l}\text { Non-smoker } \\
<255(N=611)\end{array}$ & $\begin{array}{l}\text { Smoker } \\
\geqslant 255(N=365)\end{array}$ \\
\hline $\begin{array}{l}\text { Diastolic blood } \\
\text { pressure } \\
(\mathrm{mm} . \mathrm{Hg})\end{array}$ & $\begin{array}{r}<85 \\
85-94 \\
95-104 \\
>104\end{array}$ & $\begin{array}{r}67 \\
187 \\
0 \\
1538\end{array}$ & $\begin{array}{r}280 \\
1034 \\
2000 \\
2308\end{array}$ & $\begin{array}{r}514 \\
711 \\
1042 \\
2462\end{array}$ & $\begin{array}{l}\text { IIII } \\
1885 \\
2292 \\
1818\end{array}$ \\
\hline \multicolumn{2}{|l|}{ Combined rate } & 162 & 837 & 867 & 1589 \\
\hline
\end{tabular}

the highest cholesterol values. Here there was a nearly tenfold increase in rate from the lowest blood pressure group to the highest. In the fifties, it made much less difference what the blood pressure was if the men both smoked and had the higher cholesterol concentrations. Necessarily, the number of men in these groups is not large, and the trends rather than the individual figures appear important.

Cerebrovascular episodes Seventy-one individuals were diagnosed as having nonfatal and fatal cerebrovascular episodes during the ten years of follow-up, probably an understatement of the true incidence. While the number of these events is not large, Table ro shows that in middle and older age an association between the diastolic blood pressure, including mild hypertension, and cerebrovascular events is apparent. It was also found that there was no consistent difference in the incidence of cerebrovascular episodes within the four diastolic blood pressure categories in terms of high $(255 \mathrm{mg}$./100 ml.) serum cholesterol concentrations as compared with lower (less than $255 \mathrm{mg}$./100 ml.) values.

\section{Discussion}

It may be seen from the data from this I0-year co-operative study that the occurrence in men of diastolic blood pressures between 85 and I04 $\mathrm{mm}$. $\mathrm{Hg}$ as encountered in a health survey

TABLE IO Total cerebrovascular episodes: ten-year rates/10,000 by age and blood pressure

\begin{tabular}{lccl}
\hline $\begin{array}{l}\text { Diastolic } \\
\text { blood pressure } \\
\text { (mm. Hg) }\end{array}$ & $\begin{array}{c}\text { Age 30-39 } \\
(N=1193)\end{array}$ & $\begin{array}{c}\text { Age 40-49 } \\
(N=342 I)\end{array}$ & $\begin{array}{l}\text { Age 50-59 } \\
(N=197 I)\end{array}$ \\
\hline$<85$ & 30 & 47 & 111 \\
$85-94$ & 0 & 58 & 133 \\
$95-104$ & 72 & 124 & 259 \\
$>104$ & 0 & 406 & 765 \\
\hline Combined rate & 25 & 82 & 203 \\
\hline
\end{tabular}

does have a real and unfavourable long term influence on health. Clearly linked with relative overweight, such blood pressures - as contrasted with diastolic values less than $85 \mathrm{~mm}$. $\mathrm{Hg}$ - are associated with higher total death rates, more deaths from coronary disease, more non-fatal myocardial infarctions plus deaths from coronary disease, and more cerebrovascular episodes. The presence of high serum cholesterol concentration and the use of cigarettes increases the risk of non-fatal myocardial infarctions and coronary deaths at essentially all blood pressure levels. The deleterious influence of mild elevation of diastolic blood pressure is most conspicuous in men in the fifties, and is relatively modest in men in their forties; it is also present in men in the thirties, although here the relatively small number of subjects makes the data less meaningful. The factors of age and years of exposure to a level of pressure in the peripheral arterial circulation are thus important.

There are other risks of mild hypertension needing mention. The patient with mild hypertension is rarely motivated to undertake or pursue treatment as he usually feels entirely well. The physician often evades a diagnosis of mild hypertension by recording blood pressures just below 'significant' levels. Further, he all too often evinces little or no interest in initiating screening for curable hypertension, in instructing the patient in the need for long-term care, and in following the patient with adequate regularity.

It is not too much to say that the diagnosis, study, and treatment of mild hypertension in young and middle-aged adults constitutes one of our greatest health challenges today.

\section{References}

Lew, E. A. (1967). Blood pressure and mortality - life insurance experience. In The Epidemiology of Hypertension, p. 392. Ed. by J. Stamler, R. Stamler, and T. N. Pullman. Grune and Stratton, New York. 
Mathisen, H. S., Löken, H., Brox, D., and Stenbaek, O. (1969). The prognosis in long term treated and 'untreated' essential hypertension. Acta Medica Scandinavica, 185, 253.

Metropolitan Life Insurance Company (1959). New weight standards for men and women. Metropolitan Life Insurance Company Statistical Bulletin, 40, I.

Paul, O., and Ostfeld, A. M. (1965). Epidemiology of hypertension. Progress in Cardiovascular Disease, 8, Io6.
Sokolow, M., and Perloff, D. (1961). The prognosis of essential hypertension treated conservatively. Circulation, 23, 697.

Veterans Administration Cooperative Study Group on Antihypertensive Agents (1967). Effects of treatment on morbidity in hypertension: results in patients with diastolic blood pressures averaging I 5 through $129 \mathrm{~mm}$. Hg. Fournal of the American Medical Association, 202, 1028. 